\title{
The effect of climate and soil conditions on tree species turnover in a Tropical Montane Cloud Forest in Costa Rica
}

\author{
Achim Häger \\ Center for Sustainable Development, Studies School for Field Studies, PO Box 150-4013, Atenas, Costa Rica; \\ ahaeger@fieldstudies.org
}

Received 24-VI-2010. Corrected 30-VII-2010. Accepted 06-VIII-2010.

\begin{abstract}
On a global level, Tropical Montane Cloud Forests constitute important centers of vascular plant diversity. Tree species turnover along environmental gradients plays an important role in larger scale diversity patterns in tropical mountains. This study aims to estimate the magnitude of beta diversity across the Tilarán mountain range in North-Western Costa Rica, and to elucidate the impact of climate and soil conditions on tree species turnover at a local scale. Seven climate stations measuring rainfall, horizontal precipitation (clouds and wind-driven rain) and temperatures were installed along a $2.5 \mathrm{~km}$ transect ranging from $1200 \mathrm{~m}$.a.s.1. on the Atlantic to 1200 m.a.s.l. on the Pacific slope. The ridge top climate station was located at 1500 m.a.s.l. Climate data were recorded from March through December 2003. Additionally, seven 0.05ha plots were established. On all plots soil moisture was monitored for one year, furthermore soil type and soil chemistry were assessed. Woody plants with a diameter at breast height $(\mathrm{dbh}) \geq 5 \mathrm{~cm}$ were identified to species. Species' distributions were explored by feeding pairwise Sørensen measures between plots into a Principal Component Analysis. Relationships between floristic similarity and environmental variables were analyzed using Mantel tests. Pronounced gradients in horizontal precipitation, temperatures and soil conditions were found across the transect. In total, 483 woody plants were identified, belonging to 132 species. Environmental gradients were paralleled by tree species turnover; the plots could be divided in three distinctive floristic units which reflected different topographic positions on the transect (lower slopes, mid slopes and ridge). Most notably there was a complete species turnover between the ridge and the lower Pacific slope. Floristic similarity was negatively correlated with differences in elevation, horizontal precipitation, temperatures and soil conditions between plots. It is suggested that beta-diversity in the study area is largely driven by species with narrow spatial ranges, due to the interactions between topography, climate and soil formation processes, especially around the wind-exposed and cloud covered ridge area. The findings emphasize the extraordinary conservation value of tropical montane cloud forests in environmentally heterogeneous areas at mid-elevations. Rev. Biol. Trop. 58 (4): 1489-1506. Epub 2010 December 01.
\end{abstract}

Key words: beta diversity, environmental gradients, horizontal precipitation, Monteverde Cloud Forest Reserve, soil acidity, soil water.

Mountain ranges in the humid tropics rank among the most important centers of vascular plant diversity worldwide (Myers et al. 2000, Barthlott et al. 2005, Richter 2008). According to Bruijnzeel et al. (2010) diversity hot spots in tropical mountain areas overlap widely with the spatial distribution of Tropical Montane Cloud Forests (TMCF). These forests are further known to display high levels of endemism due to localized speciation on isolated mountain tops and ridges which provide specific microhabitats (Gentry 1992, Bubb et al. 2004, Brown \& Kappelle 2001, Kappelle 2004). The high plant species richness of tropical mountain ranges results from a combination of suitable climatic conditions, geological history, disturbance regimes, the geographic convergence of species ranges, and high species turnover in 
complex geomorphologic environments (Kessler 2001, Kapelle 2004, Barthlott et al. 2005, Richter 2008, León et al. 2009). Gentry (1995) describes the changes in floristic composition along altitudinal gradients in neotropical montane forests.

Recently, several studies have identified environmental gradients that explain the distribution of diversity patterns on tropical mountains in different parts of the world. For example, Davidar et al. (2007) found that tree beta diversity was mainly driven by gradients in rainfall seasonality along an extensive mountain range in South-Western India. According to Hemp (2010), precipitation and minimum temperatures affected vascular plant diversity in different altitudinal zones of Mount Kilimanjaro. Kappelle et al. (1995) found that climatic gradients played a more important role than edaphic factors in controlling the spatial distribution of floristically distinct forest communities in Costa Rican montane oak forests. Roman et al. (2010) point out that soil conditions are widely considered to affect tropical montane forest structure and species diversity, although knowledge of soil resources in these forest ecosystems remains patchy. John et al. (2007) showed the effect of soil nutrients on the distribution of tree species in a montane forest in Columbia. Schawe et al. (2010) conclude that the interrelation between hydrometeorology and soil water conditions are determinant factors for altitudinal changes in plant diversity from lower montane forest to subalpine cloud forest in the Bolivian Andes.

To explain the patterns and processes of spatial tree species turnover in tropical forests, the influence of environmental gradients have been discussed in combination with the effects of non-deterministic mechanisms such as limited dispersal, response to historical effects, local extinctions and speciation (Pyke et al. 2001, Condit et al. 2002, Chave \& Leigh 2002, Leigh et al. 2004). Generally, the effect of the abiotic environment on species distribution is clearly traceable on the regional and landscape scales, whereas random effects become more important on the local scale (John et al. 2007).
This study aims to estimate the magnitude of beta diversity across the Tilarán mountain range in North-Western Costa Rica, from the Atlantic (windward) to the Pacific (leeward) slope, and to elucidate the impact of climate and soil conditions on patterns of tree species turnover at a local scale. Since steep gradients in precipitation, temperatures and soil conditions occur in a relatively small area between the Atlantic slope, the Pacific slope, and the cloud covered ridge area, these physical gradients should be reflected by clear differences in floristic composition between sites.

\section{MATERIALS AND METHODS}

Study site: The Tilarán mountain range forms the continental divide of the Central American isthmus in North-Western Costa Rica, extending from $10^{\circ} 25^{\prime} \mathrm{N}-84^{\circ} 50^{\prime} \mathrm{W}$ to $10^{\circ} 05^{\prime}$ $\mathrm{N}-84^{\circ} 30^{\prime} \mathrm{W}$, with its highest peaks reaching 1859m.a.s.1. (Lawton \& Dryer 1980). The mountains act as a barrier for the North-Easterly trade winds. The Caribbean slope receives more rain (up to over $7000 \mathrm{~mm}$ ) and moisture than the Pacific side (around 2000mm) which experiences a more pronounced dry season from mid-November to mid-May (Haber et al. 1996). Consequently, the environment across the Tilarán mountain range is characterized by gradients in cloud immersion, precipitation, temperature and wind speed (Clark et al. 2000, Häger \& Dohrenbusch 2010). Currently little is known about the soils in the study area which are dominated by Andisols and Inceptisols formed on volcanic parent material from the Pleistocene and older geological eras (Clark et al. 2000).

The Monteverde Cloud Forest Reserve includes the Pacific and the Atlantic slope of the continental divide and is part of a protected area complex covering almost 60 000ha (TSC 2005). The reserve harbors more than 750 tree species between $700 \mathrm{~m}$ and $1850 \mathrm{~m}$ above sea level and $10 \%$ of its flora is endemic to the Tilarán mountain range (Haber 2000). The high plant diversity of the area occurs within the context of compact altitudinal habitat zonation 
(Haber 2000). According to Bolaños \& Watson (1993) seven of Costa Rica's 12 Holdridge Life Zones are found within this relatively small area. Distinctive forest formations have been described for different habitats in Monteverde by Lawton \& Dryer (1980) and Nadkarni et al. (2000).

Environmental gradients: In January 2003, seven meteorological field stations were set up in primary forest along a $2.5 \mathrm{~km}$ transect crossing the continental divide within the Monteverde Cloud Forest Reserve and covering both Atlantic (windward) and Pacific (leeward) slopes. Stations were located approximately at corresponding altitudes $(1200 \mathrm{~m}, 1320 \mathrm{~m}$ and $1440 / 1450 m$.a.s.1.) on both sides of the continental divide, and at a central ridge-top site at 1500m.a.s.l. (Fig. 1). Rain-gauges (funnel diameter $110 \mathrm{~mm}$ ) and modified Grunow-type fog collectors (Grunow 1963) were installed on metal poles $0.5 \mathrm{~m}$ above the canopy in emergent trees which had been accessed by single rope technique. The fog collector consisted of a $0.5 \mathrm{~m}$ wire mesh cylinder with a diameter of $110 \mathrm{~mm}$. To separate cloud interception from wind-driven rain, a conical roof $(70 \mathrm{~cm}$ diameter) was installed on top of the cylinder. The instruments were connected to cans on the ground with flexible tubes. Minimum - maximum thermometers were additionally installed at each station at $1.5 \mathrm{~m}$ above the ground. Precipitation amounts and temperatures were monitored in two-week intervals from March 2003 until December 2003. This ten-month period covered the peak of the dry season (March and April) and a major part of the transitional season (November to December) which is characterized by a maximum occurrence of mist, cloud cover and wind-driven precipitation (Clark et al. 2000). Temperatures were recorded from March 2003 to February 2004.

Seven $10 x 50 \mathrm{~m}$ plots were established next to the meteorological stations. The soils of these plots were classified to suborder according to the USDA system (USDA 1999). One

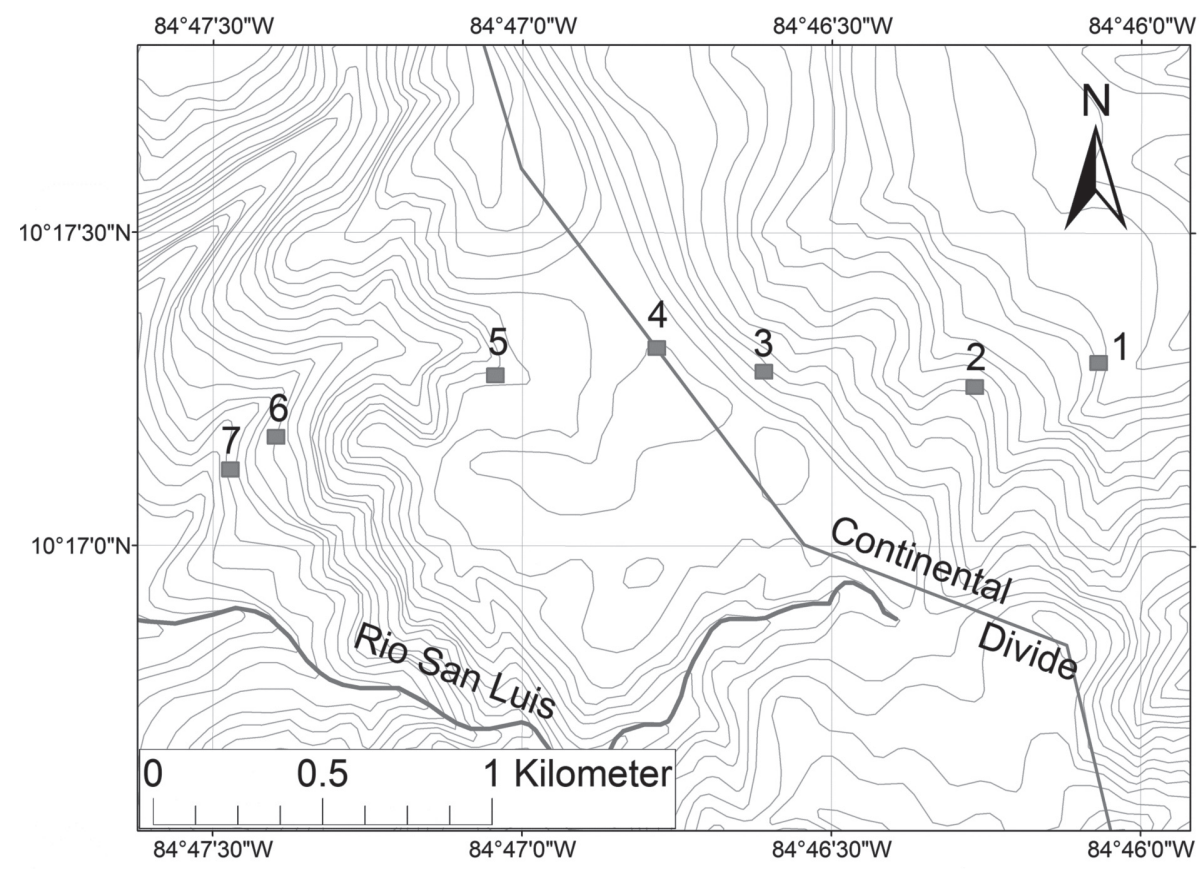

Fig. 1. Map of the study site, showing the location of the seven plots in the Monteverde Cloud Forest Reserve, Costa Rica. 
soil pit with a depth of $1 \mathrm{~m}$ was dug out at the center of each plot. On plots 2 (Atlantic slope 1320m.a.s.1.) and 4 (ridge, 1500m.a.s.1.) one pit was dug at each end, in order to account for obvious variations in topography and soil water content within the plots. Classification was based on the development of soil horizons, soil texture (according to Boden 1994), soil color (Munsell color charts, Munsell 1975), bulk density, soil moisture, cation exchange capacity (CEC) and available climatic data of the study site.

Soil cores at a depth of $30 \mathrm{~cm}$ were sampled every month from March 2003 to February 2004 at the endpoints of each plot. Volumetric soil water content was determined using the gravimetric method and weighing $100 \mathrm{~cm}^{3}$ soil samples before and after drying them at $100^{\circ} \mathrm{C}$ for at least $48 \mathrm{hrs}$, the two samples per plot were averaged.

Samples for the analysis of soil chemistry were taken at a depth of $5 \mathrm{~cm}$ in the center of each plot. On the plots 2 and 4 one sample was taken at each end, in order to account for pronounced variations in topography and soil water content, and analysis results were averaged. Samples were analyzed at the University of Costa Rica. Soil acidity (cmol/L) was measured by titration with $\mathrm{NaOH}$, after extraction with $\mathrm{KCl}$. The effective CEC was calculated from the sum of soil acidity and the concentrations of exchangeable $\mathrm{K}, \mathrm{Ca}$ and $\mathrm{Mg}(\mathrm{cmol} / \mathrm{L})$. Exchangeable $\mathrm{K}$ was extracted by the modified Olsen Method, exchangeable $\mathrm{Ca}$ and $\mathrm{Mg}$ was extracted by $\mathrm{KCl}$ and concentrations were measured with an atomic absorption spectrometer.

Forest composition: Floristic composition was assessed at seven 0.05 ha plots (see above), considering individuals with a diameter at breast height $(\mathrm{dbh}) \geq 5 \mathrm{~cm}$, including trees, shrubs, palms and tree ferns. Plants were identified in the field by William Haber and by the author. Species that could not be identified or classified as morpho-species were omitted from the analysis; this affected 19 out of 483 total individuals from all plots. On the upper Caribbean slope, on the steep headwall of the Peñas Blancas valley, only 0.02 ha of the original 0.05 ha plot were surveyed, due to the difficult topography and because the vegetation consisted of a very dense thicket of shrubs and small trees (plot 3). On the lower Pacific slope, plot 6 was originally located next to the meteorological station at 1320 m.a.s.l. Floristic composition for this site had to be assessed at a nearby plot at $1260 \mathrm{~m} . a . s .1$., since the original plot was lost after the occurrence of massive land slides.

Differences between annual average temperatures and soil moisture among sites were analyzed. Data were tested for normal distribution using the Shapiro-Wilks test. Temperature data were not normally distributed and plots were compared using a Kruskal-Wallis test. Soil water content data were normally distributed and a Bartlett test indicated homogenous variances; consequently, average annual soil moisture among plots was compared using a one-way ANOVA. Further, pairwise differences among plots were analyzed using a post-hoc Tukey-Kramer test.

According to Magurran (2004), the Sørensen Index $\left(\mathrm{C}_{\mathrm{S}}\right)$ was used for pairwise calculation of presence/absence similarity among plots:

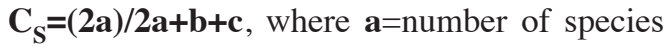
occurring in both samples, $\mathbf{b}=$ number of species occurring only in sample $\mathrm{B}$ and $\mathbf{c}=$ number of species occurring only in sample A.

Sørensen Indices were fed into a Principal Component Analysis (PCA), describing the correlation structure in species composition and abundance among all plots. The first two principal components (PC), which accounted for $61.4 \%$ of the variation in the data, were plotted to segregate plant communities across the gradient.

Following Legendre \& Legendre (1998), one-tailed Mantel tests were performed, in order to analyze relationships between floristic similarity (Sørensen Index) and differences in environmental conditions (topographic and elevational distance, rainfall, horizontal precipitation, temperatures, soil moisture and soil chemistry) between plots. The Mantel test measures the correlation between two proximity 
matrices, using all possible sample pairs. One of the advantages of this technique consists in effectively increasing the sample size on which inferences are based (Heywood 1991). The p-value was calculated using the distribution of the standardized Mantel statistic $r_{\mathrm{M}}$ which was obtained from 10000 permutations of the matrix rows and columns.

The Sørensen measure was calculated with EstimateS 8.0 (Colwell 2006). Statistical analyses were performed in JMP 7.0 (SAS 2007) and XLSTAT 2010.3.06 (Addinsoft 2009) was used for the Mantel test.

\section{RESULTS}

Environment: Rainfall from March 2003 to December 2003 was highest on plot 1, located in the Peñas Blancas Valley at 1200 m.a.s.l. on the Atlantic (windward) side of the transect (Fig. 2A). This location received more than $5000 \mathrm{~mm}$ in 10 months. At the remaining six stations rainfall varied between 3000 and $4000 \mathrm{~mm}$, without showing a clear spatial pattern with respect to the topographic gradient. Horizontal precipitation (clouds and winddriven rain) clearly followed the topographic gradient. Almost $2800 \mathrm{~mm}$ of horizontal precipitation were measured on the ridge, roughly ten times the amount of plot 1 (290mm), whereas on the lowest station on Pacific slope (plot 7), precipitation inputs from clouds were very low $(16 \mathrm{~mm})$.

The annual mean minimum temperatures were $15.5 \pm 1.3^{\circ} \mathrm{C}$ (average $\pm S D$ ) and $15.9 \pm 1.2^{\circ} \mathrm{C}$ at the lowest plots on the Atlantic and the Pacific sides, respectively and $14.5 \pm 1.5^{\circ} \mathrm{C}$ on the ridge top (Fig. 2B). Differences of annual minimum temperatures across the plots were statistically significant (Kruskal-Wallis test, $X^{2}=18.2$, d.f. $\left.=6, p=0.0053\right)$. The spatial variation in annual maximum temperatures was more pronounced: values were $22.0 \pm 1.5^{\circ} \mathrm{C}$ and $21.9 \pm 1.3^{\circ} \mathrm{C}$ on the lowest plots and almost three degrees less on the ridge at $19.2 \pm 1.2^{\circ} \mathrm{C}$ $\left(X^{2}=77.1\right.$, d.f. $\left.=6, \mathrm{p}<0.0001\right)$.

The soils of the study area have been mostly classified as Udands, Udepts and Udalfs.
Udands were typically found on the less inclined parts of the transect (plot 1, the flat section of plot 2, the Western half of plot 4). The average slope at these sites ranged between $9^{\circ}$ and $16^{\circ}$, A horizons were dark colored, indicating high organic matter contents. There were less than $20 \%$ of rocks in the $\mathrm{B}$ or $\mathrm{C}$ horizons and $\mathrm{C}$ horizons started at a depth of $70 \mathrm{~cm}$ if any were found. Udepts are characterized by less developed soil horizons and occurred in steeper areas with average slopes ranging between $36^{\circ}$ and $51^{\circ}$ (the steep section of plot 2, plots 3 and 6). Udepts showed relatively shallow A and B horizons, with $\mathrm{C}$ horizons starting at depths between 30 and $60 \mathrm{~cm}$. They were generally well drained due to the slope and to a high percentage of loose rocks in the B (30-80\%) and C (70-90\%) horizons. The completely flat,
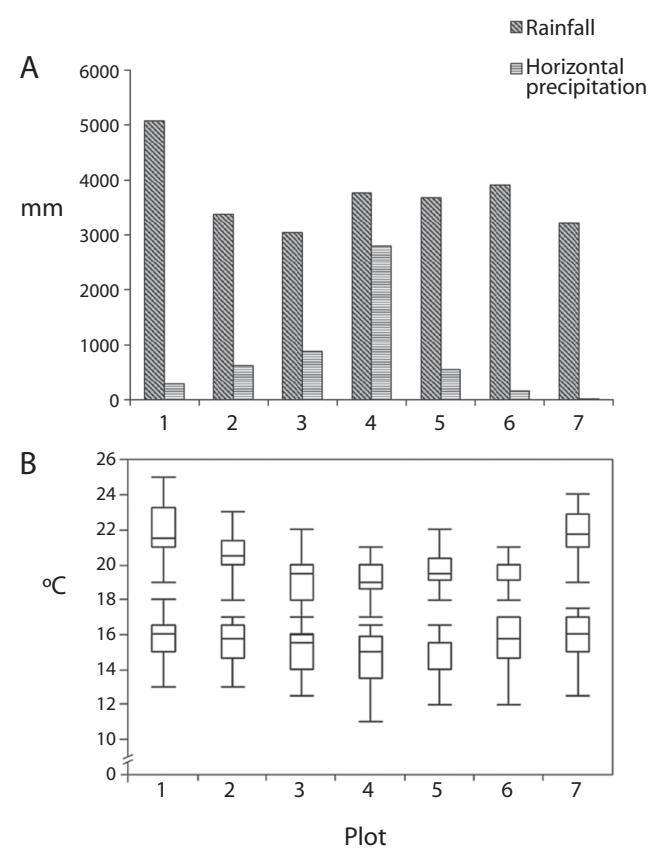

Fig. 2(A). Precipitation data measured at seven forest plots in the Monteverde Cloud Forest Reserve, Costa Rica, for the period from March 2003 to December 2003. (B) Annual minimum and maximum temperatures from March 2003 to February 2004. The box plots show Median, minimum and maximum values; the box represents $50 \%$ of the measurements. 
Eastern half of plot 4, on the ridge top was waterlogged during the wet and transitional seasons and the soil pit showed red and grey colorations in a depth between 40 and $65 \mathrm{~cm}$, indicating periodic water saturation and reduction ("redoximorphic features"), consequently these soils were classified as Aquands. On plot 5 on the upper Pacific slope, vertical translocation of clay indicated a soil of the Udalf suborder. Clay illuviation was also found in the B horizon at plot 7. Due to the effect of the dry season on soil moisture (see below), this soil can be classified as Ustalf. Near the ridge top (plots 4 and 5) organic layers reached a thickness between 2 and $3 \mathrm{~cm}$, whereas organic layers on the remaining plots ranged only between 0.5 and $1.5 \mathrm{~cm}$.

Volumetric soil water content varied significantly between the locations (Fig. 3A). On Plot 1, at 1 200m.a.s.1. on the Eastern slope, the annual average was $57 \pm 4 \%$ (average $\pm \mathrm{SD}$ ), whereas values reached around $70 \%$ in the highly organic soils around the upper slopes and at the ridge top and declined sharply with decreasing elevation on the Pacific slope to less than $40 \%$ (ANOVA, $F_{6,76}=166.0$, p<0.0001). Although plots 2 through 5 showed relatively similar soil moisture conditions, there are significant differences between the lower plots on both sides and the rest of the transect (TukeyKramer test, $\alpha=0.05$ ).

The spatial distribution of soil acidity and CEC showed an approximately inversed pattern across the transect (Fig. 3B), with the highest acidity around the ridge (Plots 4 and 5: 1.25 and $1.14 \mathrm{cmol} / \mathrm{L}$, respectively) and the highest CEC on the lower plots of the Pacific Slope (Plots 6 and 7: both 12.9 and $28.9 \mathrm{cmol} / \mathrm{L}$, respectively). CEC was found to be lowest on plot 1, at $1200 \mathrm{~m}$ on the Atlantic side $(0.85 \mathrm{cmol} / \mathrm{L})$. Base saturation (referring to exchangeable $\mathrm{Ca}, \mathrm{Mg}$ and $\mathrm{K}$ ) was relatively high on the lower Atlantic slope, ranging close to $90 \%$ on plot 1 and on the lower half of plot 2. It dropped to $49-65 \%$ between 1300 m.a.s.l. on the Atlantic side and the ridge area on the plots 2, 3 and 5. Base saturation reached almost
$100 \%$ at the lower elevations of the Pacific slope (Plots 6 and 7).

Differences in forest composition: In total, 132 woody plant species from 43 families could be identified, representing 483 individuals across all plots (Appendix). On both slopes, the highest number of species was found at the lowest elevations (1 200m.a.s.1.; Table 1).

In plot 1 (Atlantic slope, 1200 m.a.s.1.) the understory tree fern Alsophila sp. represented the most abundant species (11 individuals, $19.0 \%$ relative abundance). In addition, four individuals of both Ocotea tonduzii (Lauraceae) and Sloanea fagifolia (Elaeocarpaceae) were found, whereas the remaining 31 species only
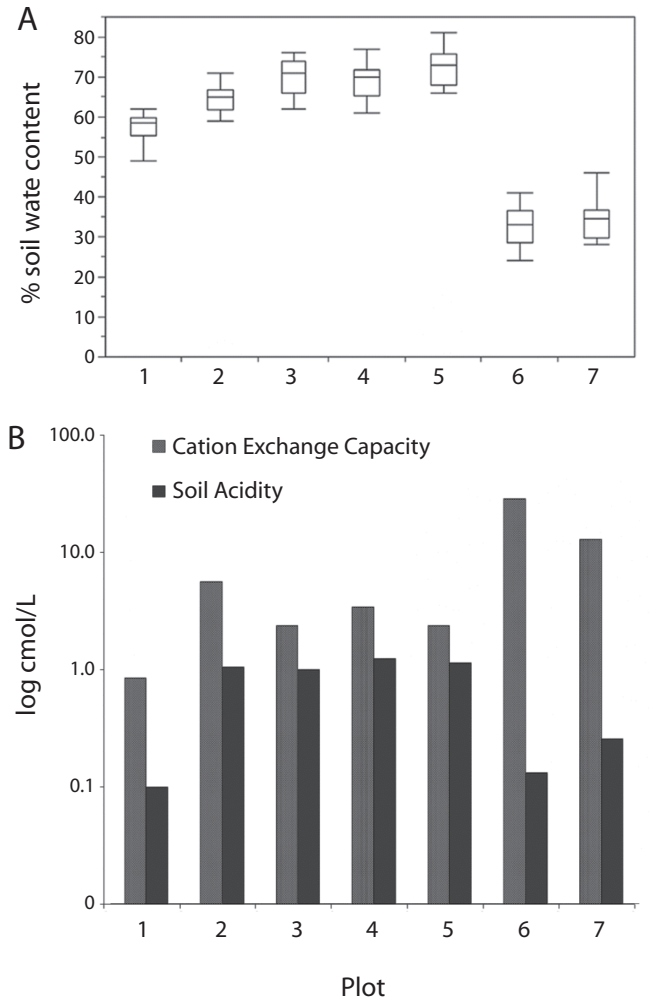

Fig. 3(A). Soil acidity and cation exchange capacity sampled in $5 \mathrm{~cm}$ depth at seven forest plots in Monteverde Cloud Forest Reserve, Costa Rica. (B) Annual volumetric soil water content at $30 \mathrm{~cm}$ depth, March 2003-February 2004. The box plots show Median, minimum and maximum values; the box represents $50 \%$ of the measurements. 
TABLE 1

Number of woody plant species $(\mathrm{dbh} \geq 5 \mathrm{~cm})$ for seven 0.05 ha forest plots at Monteverde Cloud Forest Reserve, Costa Rica

$\begin{array}{lccccccc}\text { Plot } & 1 & 2 & 3^{2} & 4 & 5 & 6 & 7 \\ \text { Altitude m as } & 1200 & 1320 & 1440 & 1500 & 1450 & 1260 & 1200 \\ \text { Slope }^{1} & \text { AS } & \text { AS } & \text { AS } & \text { Ridge } & \text { PS } & \text { PS } & \text { PS } \\ \text { n Individuals } & 58 & 77 & 60 & 98 & 59 & 64 & 67 \\ \text { n Species } & 34 & 32 & 20 & 29 & 21 & 30 & 33 \\ \text { n unknown } & 2 & 9 & 0 & 0 & 0 & 7 & 1\end{array}$

${ }^{1} \mathbf{A S}=$ Atlantic Slope; PS=Pacific Slope.

${ }^{2}$ Plot size 0.02 ha.

occurred once or twice. Plot 3 (at 1 440m.a.s.1. on the steep headwall of the Peñas Blancas Valley) was dominated by Graffenrieda micrantha (Melastomataceae) and Rondeletia monteverdensis (Rubiaceae) which accounted for 21.7 and $16.7 \%$ of all individuals, respectively. In plot 4, located on the ridge (1 500m.a.s.1.), Ardisia sp., Ardisia solomonii (Myrsinaceae) and Chrysochlamys allenii (Clusiaceae) combined accounted for $32 \%$ of all individuals. Clusia sp. occurred six times on the wet soils of this plot and dominated the low canopy of the forest with relatively extensive tree crowns. More than $50 \%$ of the species were found only once or twice. In plot 5 (Pacific slope, 1450 m.a.s.1.) the subcanopy tree Elaeagia auriculata (11 individuals, $18.6 \%$ relative abundance) represented the most abundant species, followed by the treefern Cyathea sp. (13.6\%) and by Conostegia rufescens (Melastomataceae, $10.2 \%$ relative abundance). Almost
$70 \%$ of the species occurred only once or twice, among those large canopy trees, such as Ficus crassiuscula. On the remaining plots 2, 6 and 7 relative abundance was overall low, the majority of plant species $(67-77 \%)$ were only found once or twice.

In terms of floristic similarity, there was a complete species turnover from the ridge (plot 4, at 1500 m.a.s.1.) to plots 6 and 7 on the lower Pacific slope below $1300 \mathrm{~m} . a . s .1 .$, both located only 1080 and $1220 \mathrm{~m}$ away from the continental divide, respectively (Table 2). The ridge site was relatively closely related only to plot 3 , at 1440 m.a.s.l. at the upper Atlantic slope (Sørensen measures of 0.286). Comparisons between the ridge and the remaining sites overall resulted in low similarity indices between 0 and 0.20 .

Floristic similarity was strongest among the two lowest sites on the Pacific slope, (plots 6 and 7, Sørensen Index 0.419). Notably, with

TABLE 2

Pairwise measures of floristic similarity for seven forest plots at Monteverde Cloud Forest Reserve, Costa Rica, using the Sørensen Index

\begin{tabular}{|c|c|c|c|c|c|c|c|}
\hline Altitude $\mathrm{m}$ asl, Slope ${ }^{1}$ & Plot & 1 & 2 & 3 & 4 & 5 & 6 \\
\hline 1200, AS & 1 & - & & & & & \\
\hline $1320, \mathrm{AS}$ & 2 & 0.246 & - & & & & \\
\hline 1440, AS & 3 & 0.111 & 0.275 & - & & & \\
\hline 1500, Ridge & 4 & 0.063 & 0.100 & 0.286 & - & & \\
\hline 1450, PS & 5 & 0.182 & 0.346 & 0.341 & 0.200 & - & \\
\hline $1260, \mathrm{PS}$ & 6 & 0.190 & 0.133 & 0.041 & 0 & 0.040 & - \\
\hline 1200, PS & 7 & 0.239 & 0.156 & 0.038 & 0 & 0.111 & 0.419 \\
\hline
\end{tabular}

${ }^{1}$ AS=Atlantic Slope; $\mathbf{P S}=$ Pacific Slope. 
indices between 0.040 and 0.111 , these two sites showed very low similarities with the neighboring plot 5 , located less than $700 \mathrm{~m}$ away from plot 6 at 1450 m.a.s.l. Plot 5 was more closely related to plots 2 and 3 on the Atlantic slope (Sørensen Index 0.346 and 0.341 , respectively).

Plot 1, at 1 200m.a.s.l. on the Atlantic side showed similar affinities to its neighbor plot 2 (1320m.a.s.1.) and to plot 7, located at 1 $200 \mathrm{~m}$. a.s.l. on the opposite end of the transect at a distance of $2500 \mathrm{~m}$ (Sørensen indices 0.246 and 0.239 , respectively).

The extraction of the first two principal components (PC) explained $61.4 \%$ of the total variance in species composition and abundance. The loadings of the eigenvectors (Table 3 ) show that the indices for the plots on the lower Pacific slope (6 and 7) had a high leverage on the first PC. The high positive loading from plot 2 and the negative loading from the ridge (plot 4) had the strongest influence on the magnitude of the second PC. The positions of the PC scores in Fig. 4 divide the sample plots in three distinctive units characterized by floristic similarity. These units coincide with the topographic position of the sites; in particular, plots 1, 6 and 7 represent forest types at

TABLE 3

Coefficients of the first two principal components $(P C)$ for the relationships between woody plant samples from seven plots at Monteverde Cloud Forest Reserve, based on Sorensen measures. Bold numbers indicate eigenvectors that contribute most to the differences between samples

\begin{tabular}{lcc}
\multicolumn{1}{c}{ Plot No. } & $\begin{array}{c}\text { PC 1 } \\
\text { Eigenvectors }\end{array}$ & $\begin{array}{c}\text { PC 2 } \\
\text { Eigenvectors }\end{array}$ \\
1 & -0.21 & 0.39 \\
2 & 0.16 & $\mathbf{0 . 6 3}$ \\
3 & 0.44 & -0.06 \\
4 & 0.36 & $\mathbf{- 0 . 5 5}$ \\
5 & 0.36 & 0.34 \\
6 & $\mathbf{- 0 . 4 9}$ & -0.14 \\
7 & $\mathbf{- 0 . 4 9}$ & -0.02 \\
Cumulative & & \\
percentage of & $41.0 \%$ & $61.4 \%$ \\
variance: & &
\end{tabular}

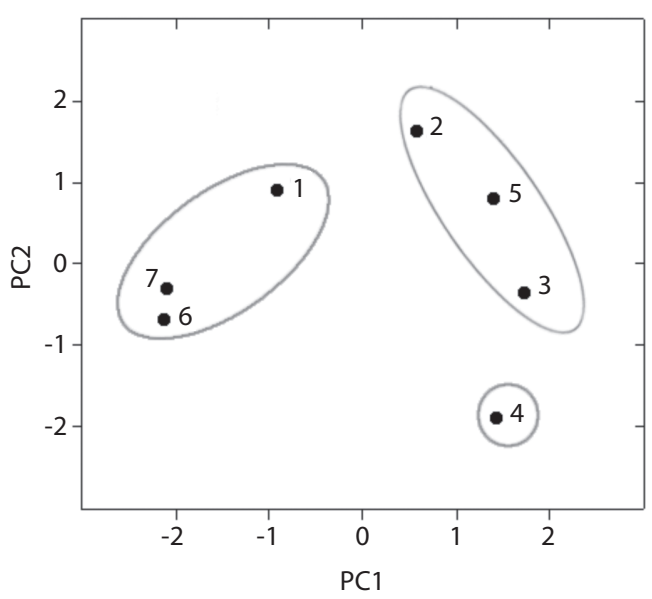

Fig. 4. Gradient analysis diagram using the first two principal components (PC) based on floristic similarity (Sørensen measures) between seven forest plots following the elevation gradient across the continental divide in the Monteverde Cloud Forest Reserve, Costa Rica. Plots 1 to 3 were located: 1 200m-1 440m.a.s.1. on the Atlantic slope, plot 4 represented the ridge at $1500 \mathrm{~m}$, plot 5 was located at $1450 \mathrm{~m}$.a.s.l. on the upper Pacific slope and plots 6 and 7 represent the lower Pacific slope between 1200 and 1 260m.a.s.1.

elevations below $1300 \mathrm{~m}$. Plots 2, 3 and 5 form a group of intermediate forests extending from 1300 m.a.s.l. on the lower Atlantic slope to 1 450m.a.s.l. the upper Pacific side but excluding the ridge community which is represented by plot 4 .

Finally, it was found that floristic similarity between plots was negatively correlated with differences in the physical environment between these sites (Table 4). Differences in elevation, horizontal precipitation, minimum temperature, soil moisture and soil chemistry were correlated with floristic composition. There was no significant relationship, between the similarity indices and topographic distance, rainfall and maximum temperatures.

\section{DISCUSSION}

Heterogeneous physical environments play an important role for plant species diversity at 
TABLE 4

Mantel test statistics representing the correlation between proximity matrices of floristic composition (Sørensen), topographic location and environmental variables $(n=7$ plots) in Monteverde Cloud Forest Reserve, Costa Rica

\begin{tabular}{cccccccccc} 
& Distance & Elevation & Rainfall & $\begin{array}{c}\text { Horizontal } \\
\text { precip. }\end{array}$ & $\begin{array}{c}\text { Minimum } \\
\text { temp. }\end{array}$ & $\begin{array}{c}\text { Maximum } \\
\text { temp. }\end{array}$ & $\begin{array}{c}\text { Soil } \\
\text { moisture }\end{array}$ & $\begin{array}{c}\text { Cation } \\
\text { exchange } \\
\text { capacity }\end{array}$ & $\begin{array}{c}\text { Soil } \\
\text { acidity }\end{array}$ \\
\hline$r_{\mathrm{M}}$ & -0.263 & -0.728 & 0.121 & -0.509 & -0.647 & -0.188 & -0.745 & -0.373 & -0.726 \\
$\mathrm{p}$ & 0.122 & 0.0002 & 0.711 & 0.008 & 0.001 & 0.211 & $<0.0001$ & 0.048 & $<0.0001$
\end{tabular}

different spatial scales in tropical mountains, because it allows for the proximity of different vegetation types and favors ecological specialization (Barthlott et al. 2005, Richter 2008). Data from this study show distinctive gradients in climate and soil conditions within a relatively small area across the continental divide of the Tilarán mountain range.

Whereas rainfall distribution did not follow a clear spatial pattern (besides a clear maximum on the lower Atlantic slope), variation in temperatures and horizontal precipitation (from clouds and wind-driven rain) were clearly related to aspect and elevation across the transect. Orographic cloud interception constitutes a major hydrological input within the study area (Clark et al. 2000, Bruijnzeel 2006, Guswa et al. 2007, Häger \& Dohrenbusch 2010) and similarly pronounced differences in cloud water interception have been demonstrated for other TMCF sites in Central America (Cavelier et al. 1996, Holder 2003). Due to high amounts of rainfall plus horizontal precipitation, the ridge plot effectively experienced extremely humid conditions. This hydrological surplus is further increased by low evapotranspiration, as it occurs in the cloud-exposed areas at higher elevations of the Tilarán mountains (Bruijnzeel 2006).

Similarly, the spatial distribution of soil chemistry and soil water content were related to topographic position across the study area. According to Clark et al. (2000) exposure to precipitation from rain and clouds coincide with edaphic gradients in the Tilarán mountain range. Richter (2008) emphasizes the importance of climatic factors for soil formation processes on tropical mountains and points out that mid-elevation precipitation maxima can affect soil fertility through leaching processes. Roman et al. 2010 found correlations between soil chemistry ( $\mathrm{pH}$ and base saturation) and precipitation across 33 different TMCF sites. The relatively high soil acidity and low base saturation on the flat ridge area are likely to be related to lower temperatures and excessive precipitation. These can lead to waterlogging and consequently to lower decomposition rates (Kappelle et al. 1995, Benner et al. 2010, Schawe et al. 2010). At the study site, high soil water contents and thicker layer of organic material occurred around the ridge area. The accumulation of humus, especially on allophone rich soils (as Andisols), leads to a large proportion of immobilized nutrients and the production of acids from decomposing organic matter further contributes to nutrient cation leaching (Grubb 1977, Clark et al. 2000, Kappelle 2004). Accordingly, Schawe et al. (2010) describe how the hydrological balance affected soil water status and chemistry along an altitudinal gradient in the Bolivian Andes which in turn played an important role for plant species distribution.

Data from this study demonstrate that differences in climate and soil conditions are paralleled by species turnover across forest plots. The strongest differences, both environmentally and floristically occurred across a horizontal distance of roughly $1 \mathrm{~km}$ between the ridge and the lower Pacific slope. Along this section of the transect, horizontal precipitation decreased to less than $1 \%$ compared to the maximum amount on the ridge, temperatures increased 
at a higher rate than on the Atlantic slope, soil water content dropped sharply and soil chemistry changed from the most adverse to the most favorable for plant growth. Bruijnzeel \& Hamilton (2000) and Richter (2008) note that frequent cloud cover at ground level often coincides with pronounced changes in forest structure and floristic composition of TMCF, compared to the zone below cloud incidence. The wind exposed and cloud immersed ridge (plot 4) was covered by dense, stunted vegetation that can be described as an elfin cloud forest (sensu Bruijnzeel 2001) and species turnover was complete between this site and the taller forests below $1300 \mathrm{~m}$ on the Pacific slope (plots 6 and 7). Species overlap between plots 6 and 7 and the upper Atlantic and Pacific slopes (plot 3 and 5, both above 1 400m.a.s.1.) was minimal as well.

Many of the species found at the ridge plot are described by Haber (2000) as characteristic plants for the atmospheric and edaphic conditions of the wind exposed elfin forest in Monteverde: Ardisia solomonii (Myrsinaceae), Clusia sp. (Clusiaceae), Rondeletia monteverdensis and Cosmibuena valerii (Rubiaceae), Dendropanax gonatopodus (Araliaceae), Conostegia pittierii, Conostegia rhodopelata and Miconia tonduzii (Melastomataceae). Chrysoclamys allennii (Clusiaceae) was one of the most important species around the ridge area, this small tree is closely associated with wet soils (Haber 2000) and frequent cloud cover (Zamora et al.2004). According to a list published by SINAC (2007), 13 of the species identified by this study are endemic to Costa Rica (10\%). Four endemic species were found on the ridge plot, accounting for $14 \%$ of the species at this site (Rondeletia monteverdensis, Symplocos tribracteolata, Inga longispica and Oreopanax nubigenus). Gentry (1992) points out that that endemism occurs on an extremely localized scale along cloud forest ridges in Southern Central America. He suggests that many endemic cloud forest plants are specialized to unusual habitats and originate from highly dynamic speciation.
There was a moderate floristic similarity between plot 4 and the neighboring plot 3 , located at 1440 m.a.s.l., on the wind-exposed, steep headwall of the Peñas Blancas valley (average slope $51^{\circ}$ ). Furthermore, both forest types showed canopy heights around or under $10 \mathrm{~m}$. According to (Scatena \& Lugo 1995) geomorphology determined drainage conditions, downslope mass movement and slope stability which in turn influenced the structure and composition of tropical forests in Puerto Rico at a local scale. Bellingham \& Sparrow (2009) point out that steep slopes affect the vegetation of montane rain forests by increased ground surface disturbance and decreased availability of nitrogen. Consequently, on the steep upper Atlantic slope, additional edaphic stress factors such as landslides and top soil erosion can contribute to the local formation of stunted and floristically distinct cloud forest types in Monteverde.

This study shows evidence for the distribution of woody plant species in accordance with varying environmental factors. Differences in elevation proved to be related with floristic similarity, whereas the correlation between horizontal distance and similarity among plots was not significant. Thus, the effect of Atlantic vs. Pacific slope was not of great importance in the geographical range covered by the study area. This could be partly due to the limited size and number of forest plots. Rainfall amount and seasonality is likely to be of very high importance on a larger spatial scale. Other physical factors, associated with elevation and geomorphology, turned out to be closely related to spatial species turnover on a local scale, most importantly soil moisture and acidity, followed by minimum temperatures and differences in horizontal precipitation, which are due to varying exposition to cloud interception and constant trade winds. These results suggest that the interrelations of topographic, climatic and edaphic factors contribute largely to plant species turnover in the cloud forests of the Tilarán mountains. In particular, climate and topography determine soil conditions which 
may constitute a strong proximate factor for floristic forest composition.

The importance of environmental gradients for beta diversity in this area is reinforced by findings for other taxonomic groups. According to Jankowski \& Rabenold (2007) and Jankowski et al. (2009), bird communities were closely related to the moisture gradient across the mountain range and contained a high proportion of species endemic to Costa Rica and Panama. Species turnover was almost complete within a few kilometers between the continental divide and the drier and seasonal Pacific slope. On the other hand, as birds are important for seed dispersal, it becomes evident that biotic interactions play a decisive role for spatial tree species turnover, as well.

Although heterogeneity of the physical environment does clearly contribute to species turnover in tropical trees, it interacts in a complex way with historical and stochastic factors which are difficult to distinguish, especially at smaller spatial scales (Condit et al. 2002, Leigh et al. 2004, Davidar et al. 2007, John et al. 2007) and which the present study cannot account for.

It must be noted that the conclusions from this study about relationships between environmental factors and plant species distributions remain tentative to a certain extent, due to the limited floristic dataset. Given the plot size of $0.05 \mathrm{ha}$, and the lack of replications at the different altitudes, it cannot be expected that woody plant compositions ( $\mathrm{dbh} \geq 5 \mathrm{~cm}$ ) are fully representative. Furthermore, it has been argued that correlations between environmental variables and diversity patterns are problematic, because they do not necessarily imply causal mechanisms (Ricklefs 2004).

Despite the limitations of the study, it presents a continuous dataset from 10 months of climate and soil moisture data, soil chemistry, and tentative floristic composition from a variety of cloud forest habitats located in an area of difficult access. Currently, there is limited information available about the relationship of the physical environment and plant communities in this area. These data show clear tendencies of species turnover along environmental gradients and indicate that the interrelations between topography, climate and soil formation contribute to spatial species distribution, which is in agreement with a growing body of information on TMCF ecology.

The spatial arrangement of species diversity within landscapes and the concentration of endemics have important implications for defining conservation priorities and ecosystem management guidelines (Gentry 1992, Myers et al. 2000, Condit et al. 2002, Magurran 2004). Tropical montane landscapes with a high beta diversity, such as the Monteverde area, provide refuge for many species with restricted ranges and specialized habitat requirements in the face of threats to biodiversity resulting from climate change and habitat loss (Jankowski et al. 2009).

In conclusion, this study shows how contrasting environmental conditions contribute to woody plant species turnover in the Tilarán mountain range. Excess precipitation (from rain and cloud interception) and low temperatures lead to water logging, slow mineralization rates, exchangeable base depletion and soil acidity around the ridge. The interrelation of climate and edaphic factors in turn play an important role for the spatial distribution of plant species. The wet and wind exposed ridge area is covered by elfin cloud forest and seems to provide habitats for species with narrow ranges and specialized requirements, including many endemics. These factors lead to a high tree species turnover in a relatively small area which contributes to the striking plant diversity of the Monteverde area on a larger scale. The findings emphasize the extraordinary conservation value of tropical montane forests in environmentally heterogeneous areas, especially at mid-elevations. More research is needed, supported by remote sensing techniques, to gain more comprehensive insights into the complex processes that maintain biological diversity in tropical mountain areas of difficult access. 


\section{ACKNOWLEDGMENTS}

I wish to thank William Haber for species identification, Przemyslaw Walotek for invaluable help in the field and Achim Dohrenbusch for support and input throughout the study. Further, I thank the Tropical Science Center for permission to work in the Monteverde Reserve and for its kind cooperation during fieldwork. I am very grateful for inspiration and support from Gerardo Avalos. Edgardo Arevalo, Brian Gill and an anonymous reviewer provided helpful comments on earlier versions of the manuscript. This study was financed by the German Research Council (DFG).

\section{RESUMEN}

A nivel global, los bosques nubosos tropicales constituyen importantes centros de diversidad florística. El recambio de especies a través de gradientes ambientales juega un papel importante en los patrones de diversidad en las montañas tropicales. Este estudio tiene como objetivo estimar la diversidad beta de plantas leñosas a través de la Cordillera de Tilarán en el noroeste de Costa Rica y aclarar el impacto del clima y las condiciones del suelo en la distribución de especies a una escala local. Se instalaron siete estaciones meteorológicas, en las cuáles se midió lluvia, precipitación horizontal y temperatura, a lo largo de un transecto de $2.5 \mathrm{~km}$ desde $1200 \mathrm{msnm}$ de altitud en la vertiente Atlántica a 1 200msnm en la vertiente Pacífica. La estación de la cima se localizó a 1 500msnm. Los datos climáticos se registraron entre marzo y diciembre del 2003. Además, se establecieron siete parcelas de 0.05 ha. En cada parcela se monitoreó la humedad del suelo por un año. Se determinaron los tipos de suelo y sus propiedades químicas. Las plantas leñosas con un diámetro $\geq 5 \mathrm{~cm}$ fueron identificadas. La distribución de las especies fue explorada insertando las medidas Sørensen entre parcelas en un Análisis de Componentes Principales. Las relaciones entre la similitud florística y las variables ambientales se analizaron mediante pruebas de Mantel. Se encontraron gradientes pronunciados en la precipitación horizontal, temperaturas y condiciones del suelo a través del transecto. En total, se identificaron 483 plantas leñosas, pertenecientes a 132 especies. El recambio de especies leñosas se efectuó de forma paralela a los gradientes ambientales; según los análisis las parcelas se dividen en tres unidades distintivas florísticas que reflejan diferentes posiciones topográficas del transecto. Notablemente se produjo un recambio total de especies entre la cima y la vertiente Pacifica inferior. La similitud florística fue correlacionada negativamente con las diferencias de altitud, precipitación horizontal, temperaturas y condiciones del suelo entre las parcelas. Se sugiere que la diversidad beta en el área de estudio resulta en gran parte de la distribución de especies con rangos limitados, debido a las interacciones entre la topografía, el clima y los procesos de formación del suelo, especialmente alrededor de la cima que está expuesta a los vientos alisios y frecuentemente cubierta de nubes. Los resultados subrayan el valor de conservación extraordinaria que tienen los Bosques Nubosos Tropicales en áreas ambientalmente heterogéneas en alturas medianas.

Palabras clave: acidez de suelo, diversidad beta, humedad de suelo, Reserva Biológica de Bosque Nuboso Monteverde, precipitación horizontal.

\section{REFERENCES}

Addinsoft. 2009. XLSTAT. 4.05. Addinsoft, New York, USA.

Barthlott, W., J. Mutke, D. Rafiqpoor, G. Kier \& H. Kreft. 2005. Global centers of vascular plant diversity. Nov. Act. L.C. 342: 61-83.

Bellingham, P.J. \& A.D. Sparrow. 2009. Multi-stemmed trees in montane rain forests: their frequency and demography in relation to elevation, soil nutrients and disturbance. J. Ecol. 97: 472-483.

Benner, J., P. Vitousek \& R. Ostertag. 2010. Nutrient cycling and nutrient limitation in tropical montane cloud forests. In L.A. Bruijnzeel, F.N. Scatena \& L.S. Hamilton (eds.). Tropical Montane Cloud Forests, Science for Conservation and Management. Cambridge, Cambridge, England (in press).

Boden, A.G.. 1994. Bodenkundliche Kartieranleitung. Bundesanstalt für Geowissenschaften und Rohstoffe und Geologische Landesämter, Hannover, Germany.

Bolaños, R.A. \& V. Watson. 1993. Mapa ecológico de Costa Rica según el sistema de clasificación de Zonas de Vida de L.R. Holdridge. Centro Científico Tropical, San José, Costa Rica.

Brown, A.D. \& M. Kappelle. 2001. Introducción a los bosques nublados del neotrópico: una síntesis regional, p. 25-40. In M. Kappelle \& A.D. Brown (eds.). Bosques nublados del neotrópico. Instituto Nacional de Biodiversidad, Santo Domingo de Heredia, Costa Rica.

Bruijnzeel, L.A. 2001. Hydrology of tropical montane cloud forests: a reassessment. Land Use and Water Resources Research 1: $1.1-1.18$.

Bruijnzeel, L.A. 2006. Hydrological impacts of converting tropical montane cloud forest to pasture, with initial reference to Northern Costa Rica. Final Technical 
Report for Project R7991, DFID Forestry Research Programme. VU University Amsterdam, Amsterdam, Netherlands.(also avaible online: www.ambiotek. com/fiesta)

Bruijnzeel, L.A. \& L.S. Hamilton. 2000. Decision time for cloud forests. IHP Humid Tropics Programme Series No.13. UNESCO, Paris, France.

Bruijnzeel, L.A., M. Kappelle, M. Mulligan \& F.N. Scatena. 2010. Tropical montane cloud forests: state of knowledge and sustainability perspectives in a changing world. In L.A. Bruijnzeel, F.N. Scatena \& L.S. Hamilton (eds.). Tropical Montane Cloud Forests, Science for Conservation and Management. Cambridge, Cambridge, England (in press).

Bubb, P., I. May, L. Miles \& J. Sayer. 2004. Cloud Forest Agenda. UNEP-WCMC, Cambridge, England.

Cavelier, J., D. Solís \& M.A. Jaramillo. 1996. Fog interception in montane forests across the Central Cordillera of Panama. J. Trop. Ecol. 12: 357-369.

Chave, J. \& E.G. Leigh. 2002. A Spatially explicit neutral model of $\beta$-diversity in tropical forests. Theor. Popul. Biol. 62: 153-167.

Clark, K.L., R.O. Lawton \& P.R. Butler. 2000. The Physical Environment, p. 16-38. In N.M. Nadkarni \& N.T. Wheelwright (eds.). Monteverde: ecology and conservation of a tropical montane cloud forest. Oxford, Oxford, England.

Colwell, R.K. 2006. EstimateS: Statistical estimation of species richness and shared species from samples. Version 8. University of Connecticut, Mansfield, Connecticut, USA. (also available online: http:// viceroyeebuconnedu/EstimateS).

Condit, R., N. Pitman, E.G. Leigh, J. Chave, J. Terborgh, R.B. Foster, P. Nuñez, S. Aguilar, R. Valencia, G. Villa, H.C. Muller-Landau, E. Losos \& S.P. Hubbell. 2002. Beta-diversity in tropical forest trees. Science 2958: 666-669.

Davidar, P., B. Rajagopal, D. Mohandass, J.P. Puyravaud, R. Condit, S.J. Wright \& E.G. Leigh. 2007. The effect of climatic gradients, topographic variation and species traits on the beta diversity of rain forest trees. Global Ecol. Biogeogr. 16: 510-518.

Gentry, A.H. 1992. Tropical forest biodiversity: distributional patterns and their conservational significance. Oikos 63: 19-28.

Gentry, A.H. 1995. Patterns of diversity and floristic composition in neotropical montane forests, p. 103-126. In S.P. Churchill, H. Balsev, E. Forero \& J.L. Luteyn (eds.). Biodiversity and Conservation of Neotropical Montane Forests. New York Botanical Garden, New York, USA.

Grubb, P.J. 1977. Control of forest growth and distribution on wet tropical mountains with special reference to mineral nutrition. Annu. Rev. Ecol. Syst. 8: 38-107.

Grunow, J. 1963. Weltweite Messungen des Nebelniederschlags nach der Hohenpeissenberger Methode. International Union of Geodesy and Geophysics, General Assembly, Berkeley, California, 19-31 August 1963. International Association of Scientific Hydrology, California, USA.

Guswa, A.J., A.L. Rhodes \& S.E. Newell. 2007. Importance of orographic precipitation to the water resources of Monteverde, Costa Rica. Adv. Water Resour. 30: 2098-2112.

Haber, W.A. 2000. Plants and vegetation, p. 39-94. In N.M. Nadkarni \& N.T. Wheelwright (eds.). Monteverde: ecology and conservation of a tropical montane cloud forest. Oxford, Oxford, England.

Haber, W., W. Zuchowski \& E. Bello. 1996. An introduction to cloud forest trees: Monteverde, Costa Rica. La Nación, San José, Costa Rica.

Häger, A. \& A. Dohrenbusch. 2010. Hydrometeorology and structure of tropical montane cloud forests under contrasting biophysical conditions. Hydrol. Process. (in press).

Hemp, A. 2010. Altitudinal zonation and diversity patterns in the forests of Mount Kilimanjaro, Tanzania. In L.A. Bruijnzeel, F.N. Scatena \& L.S. Hamilton (eds.). Tropical Montane Cloud Forests, Science for Conservation and Management. Cambridge, Cambridge, England (in press).

Heywood, J.S. 1991. Spatial Analysis of genetic variation in plant populations. Annu. Rev. Ecol. Syst. 22: 335-355.

Holder, C.D. 2003. Fog precipitation in the Sierra de las Minas Biosphere Reserve, Guatemala. Hydrol. Process. 17: 2001-2010.

Jankowski, J.E. \& K.N. Rabenold. 2007. Endemism and local rarity in birds of neotropical montane rainforest. Biol. Conserv. 138: 453-463.

Jankowski, J.E., A.L. Ciecka, N.Y. Meyer \& K. Rabenold. 2009. Beta diversity along environmental gradients: Implications of habitat specialization in tropical montane landscapes. J. Anim. Ecol. 78: 315-327. 
John, R., J.W. Dalling, K.E. Harms, J.B. Yavitt, R.F. Stallard, M. Mirabello, S.P. Hubbell, R. Valencia, H. Navarette, M. Vallejo \& R.B. Foster. 2007. Soil nutrients influence spatial distributions of tropical tree species. P. Natl. Acad. Sci. USA. 104: 864-869.

Kappelle, M. 2004. Tropical montane forests, p. 17821793. In S. Burley, J. Evans \& J.A. Youngquist (eds.). Encyclopedia of forest sciences. Elsevier, Oxford, England.

Kappelle, M, J.G. Van Uffelen \& A.M. Cleef. 1995. Altitudinal zonation of montane Quercus forests along two transects in Chirripó National Park, Costa Rica. Vegetatio 119: 119-153.

Kessler, M. 2001. Patterns of diversity and range size of selected plant groups along an elevational gradient in the Bolivian Andes. Biodivers. Conserv. 10: $1897-$ 1921.

Lawton, R.O. \& V. Dryer. 1980. The vegetation of the Monteverde Cloud Forest Reserve. Brenesia 18: 101-116.

Legendre, P. \& L. Legendre. 1998. Numerical Ecology. Elsevier, Amsterdam, Holland.

Leigh E.G., P. Davidar, C.W. Dick, J.P. Puyravaud, J. Terborgh, H. ter Steege \& S.J. Wright. 2004. Why do some tropical forests have so many species of trees? Biotropica 36: 447-473.

León, J.D., G. Vélez \& A.P. Yepes. 2009. Estructura y composición florística de tres robledales en la región norte de la cordillera central de Colombia. Rev. Biol. Trop. 57: 1165-1182.

Magurran, A.E. 2004. Measuring biological diversity. Blackwell, London, England.

Munsell. 1975. Munsell soil color charts. Munsell Color Company, Baltimore, Maryland, USA.

Myers, N., R.A. Mittermeier, C.G. Mittermeier, G.A.B. Da Fonseca \& J. Kent. 2000. Biodiversity hotspots for conservation priorities. Nature 403: 853-858.

Nadkarni, N.M., R.O. Lawton, K.L. Clark, T.J. Matelson \& D. Schaefer. 2000. Ecosystem ecology and forest dynamics, p. 303-350. In N.M. Nadkarni \& N.T. Wheelwright (eds.). Monteverde: ecology and conservation of a tropical montane cloud forest. Oxford, Oxford, England.
Pyke, C.R., R. Condit, S. Salomón \& S. Lao. 2001. Floristic composition across a climatic gradient in a neotropical lowland forest. J. Veg. Sci. 12: 555-566.

Richter, M. 2008. Tropical mountain forests - distribution and general features, p. 7-24. In S.R. Gradstein, J. Homeier \& D. Gansert. The Tropical Mountain Forest - Patterns and Processes in a Biodiversity Hotspot. Centre for Biodiversity and Ecology, Göttingen, Germany.

Ricklefs, R.E. 2004. A comprehensive framework for global patterns in biodiversity. Ecol. Lett. 7: 1-15.

Roman, L., F.N. Scatena \& L.A. Bruijnzeel. 2010. Global and local variations in tropical montane cloud forest soils. In L.A. Bruijnzeel, F.N. Scatena \& L.S. Hamilton (eds.). Tropical Montane Cloud Forests, Science for Conservation and Management. Cambridge, Cambridge, England (in press).

SAS. 2007. JMP 7.0. SAS Institute Inc. Cary, North Carolina, USA.

Scatena, F.N. \& A.E. Lugo. 1995. Geomorphology, disturbance, and the soil and vegetation of two subtropical wet steepland watersheds of Puerto Rico. Geomorphology 13: 199-213.

Schawe, M., G. Gerold, K. Bach \& S.R. Gradstein. 2010. Hydrometeorological patterns in relation to montane forest types along an elevational gradient in the Yungas of Bolivia. In L.A. Bruijnzeel, F.N. Scatena \& L.S. Hamilton (eds.). Tropical Montane Cloud Forests, Science for Conservation and Management. Cambridge, Cambridge, England (in press).

SINAC. 2007. GRUAS II: propuesta de ordenamiento territorial para la conservación de biodiversidad de Costa Rica. Volumen1: análisis de vacíos en la representatividad e Integridad de la biodiversidad terrestre. Sistema Nacional de Áreas de Conservación (SINAC) del Ministerio de Ambiente y Energía (MINAE), San José, Costa Rica.

TSC. 2005. Plan de Manejo de la Reserva Biológica Monteverde, Tropical Science Center, San José, Costa Rica.

USDA. 1999. Soil taxonomy - a basic system of soil classification for making and interpreting soil surveys. United States Department of Agriculture, Natural Resources Conservation Service, Washington D.C., USA.

Zamora, N., Q. Jiménez \& L. Poveda. 2004. Árboles de Costa Rica Vol. III. Instituto Nacional de Biodiversidad, Santo Domingo de Heredia, Costa Rica. 


\section{APPENDIX}

Full list of woody plant species $(\mathrm{dbh} \geq 5 \mathrm{~cm})$ on all forest plots along a $2.5 \mathrm{~km}$ transect across the continental divide in the Monteverde Cloud Forest Reserve, Costa Rica

\begin{tabular}{|c|c|c|c|c|c|c|c|}
\hline \multirow{2}{*}{ Species } & \multicolumn{7}{|c|}{ Plot } \\
\hline & 1 & 2 & 3 & 4 & 5 & 6 & 7 \\
\hline Alchornea latifolia & & & & & & & 1 \\
\hline Allophylus occidentalis & & & & & & 1 & \\
\hline Alsophila sp. & 11 & & & & 3 & & 3 \\
\hline Ardisia "aleman" & 1 & & & & & & \\
\hline Ardisia palmana & & 5 & 2 & & 2 & & \\
\hline Ardisia solomonii & & & & 12 & & & \\
\hline Ardisia sp. near compressa & & & & 8 & & & \\
\hline Bunchosia macrophylla & & & & & & 1 & \\
\hline Bunchosia veluticarpa & & 1 & & & & 1 & \\
\hline Calyptranthes pittieri & & 1 & & 5 & & & \\
\hline Capparis discolor & & & & & & & 1 \\
\hline Casearia sylvestris & & & & & & 1 & 1 \\
\hline Casearia tacanensis & 1 & 1 & & & & & \\
\hline Cecropia obtusifolia & 1 & & & & & & \\
\hline Cecropia polyphlebia & 2 & 2 & & & & & \\
\hline Cedrela tonduzii & & & & & & 1 & 1 \\
\hline Chione silvícola & & & & & & & 1 \\
\hline Chrysochlamys allenii & 1 & 1 & 3 & 11 & 1 & & \\
\hline Chrysochlamys glauca & & 1 & & & & & 4 \\
\hline Clethra pyrogena & & & & 4 & & & \\
\hline Clusia sp. "divide" & & & & 6 & & & \\
\hline Conostegia "petiole glands" & & 2 & & & & & \\
\hline Conostegia oerstediana & & & & & & & 1 \\
\hline Conostegia pittierii & & & & 2 & & & \\
\hline Conostegia rhodopetala & & & 2 & & & & \\
\hline Conostegia rufescens & & 1 & & & 6 & & \\
\hline Conostegia sp. & 1 & & & & & & \\
\hline Conostegia vulcanicola & & 1 & & & & & \\
\hline Cordia croatii & & & & 1 & & & \\
\hline Cordia lucidula & & & & & & & 3 \\
\hline Cosmibuena valerii & & & 3 & 5 & & & \\
\hline Coussarea caroliana & 1 & & & & & & \\
\hline Cyathea sp. & & & & & 8 & & \\
\hline Dendropanax "large leaf" & & 7 & 1 & & 1 & & \\
\hline Dendropanax gonatopodus & & & & & 3 & & \\
\hline Dendropanax latilobus & & & & 3 & & & \\
\hline Dendropanax querceti & & 1 & & & & & \\
\hline Diospyros hartmanniana & 1 & & & & & & \\
\hline Dussia "monteverde" & 1 & & & & 1 & & \\
\hline Elaeagia auriculata & 2 & 7 & 1 & & 11 & & 1 \\
\hline Eugenia austin-smithii & & & & 3 & & & \\
\hline
\end{tabular}




\section{APPENDIX (Continued)}

Full list of woody plant species $(\mathrm{dbh} \geq 5 \mathrm{~cm})$ on all forest plots along a $2.5 \mathrm{~km}$ transect across the continental divide in the Monteverde Cloud Forest Reserve, Costa Rica

$\quad$ Species
Eugenia valerii
Euonymus costaricensis
Faramea ovalis
Ficus crassiuscula
Ficus hartwegii

Ficus maxima

Ficus sp.

Geonoma interrupta

1

Graffenrieda micrantha

2

Guarea "big leaf"

Guarea "veinous"

Guarea kunthiana

Guarea rhopalocarpa

Guarea tonduzii

Guatteria oliviformis

Guettarda poasana

Hampea appendiculata

Hasseltia floribunda

Heliocarpus americanus

Hyeronima oblonga

Inga hentonii

Inga longispica

Koanophyllon pittieri

Lonchocarpus oliganthus

Lozania mutisiana

Malpighia albiflora

"Melastomataceae 1"

Meliosma idiopoda

Meliosma vernicosa

Meriania phlomoides

Miconia brenesii

Miconia tonduzii

Mollinedia pinchotiana

Mortoniodendron costaricense

Mortoniodendron guatemalense

Myrcianthes rhopaloides

Myriocarpa longipes

"Myrtaceae 1"

Nectandra smithii

Ocotea "small leaf"

Ocotea "tajo"

Ocotea floribunda

1

1

2

1

5

$\begin{array}{llll}4 & 5 & & \\ & & 4 & 4 \\ & & \end{array}$

3

1

(2) 1

12

1

1

$5 \quad 1$

2

5

1

(1)




\section{APPENDIX (Continued)}

Full list of woody plant species $(\mathrm{dbh} \geq 5 \mathrm{~cm})$ on all forest plots along a $2.5 \mathrm{~km}$ transect across the continental divide in the Monteverde Cloud Forest Reserve, Costa Rica

$\quad$ Species
Ocotea haberii
Ocotea meziana
Ocotea praetermissa
Ocotea tonduzii
Ocotea viridiflora
Oreopanax nubigeus
Oreopanax xalapensis
Ossaea micrantha
Palicourea padifolia
Piper sp.
Pleurothyrium palmanum
Pouteria congestifolia
Pouteria exfoliata
Pouteria fossicola
Pouteria osteniana
Pseudolmedia mollis
Psychotria eurycarpa
Psychotria grandistipula
Pterocarpus rohrii
Quararibea costaricensis
Randia "bullpen"
Randia sylvicola
Rauvolfia aphlebia
Rondeletia buddleioides

Rondeletia monteverdensis

Rondeletia torresii

Saurauia montana

1

Plot

1

$4 \quad 6$

1

1

Saurauia sp. "divide"

Saurauia sp. "pendant"

Schefflera rodrigueziana

Sloanea brenesii

Sloanea fagifolia

Solanum rovirosanum

Sorocea trophoides

2

Styrax argenteus

Symphonia globulifera

10

4

Symplococarpon purpusii

Symplocos costaricana

2

Symplocos tribracteolata

Tabernaemontana longipes

"Treefern 1"

1

"Treefern 2" 


\section{APPENDIX (Continued)}

Full list of woody plant species $(\mathrm{dbh} \geq 5 \mathrm{~cm})$ on all forest plots along a $2.5 \mathrm{~km}$ transect across the continental divide in the Monteverde Cloud Forest Reserve, Costa Rica

\begin{tabular}{|c|c|c|c|c|}
\hline Species & & Plot & & \\
\hline Trophis mexicana & & & 5 & 1 \\
\hline "Unidentified 1" & 5 & & & \\
\hline Viburnum venustum & 1 & 2 & & \\
\hline Weinmannia wercklei & & 1 & & \\
\hline Wercklea insignis & 1 & & & \\
\hline Zanthoxylum juniperinum & & & 1 & \\
\hline Zanthoxylum melanostictum & & 2 & & \\
\hline
\end{tabular}

